\title{
The Level of Practicing the Requirements of Active Learning by Islamic Education Teachers Enrolled at King Khalid University in Asir Region
}

\author{
Omar Abdel Qader Shamalti \\ Curricula and Instruction of Islamic Sciences, Faculty of Education, King Khalid University, Abha, Saudi Arabia
}

Received August 29, 2020; Revised November 2, 2020; Accepted November 11, 2020

\section{Cite This Paper in the following Citation Styles}

(a): [1] Omar Abdel Qader Shamalti , "The Level of Practicing the Requirements of Active Learning by Islamic Education Teachers Enrolled at King Khalid University in Asir Region," Universal Journal of Educational Research, Vol. 8, No. 12, pp. 6808 - 6817, 2020. DOI: 10.13189/ujer.2020.081247.

(b): Omar Abdel Qader Shamalti (2020). The Level of Practicing the Requirements of Active Learning by Islamic Education Teachers Enrolled at King Khalid University in Asir Region. Universal Journal of Educational Research, 8(12), 6808 - 6817. DOI: 10.13189/ujer.2020.081247.

Copyright $\bigcirc 2020$ by authors, all rights reserved. Authors agree that this article remains permanently open access under the terms of the Creative Commons Attribution License 4.0 International License

\begin{abstract}
This study identified the level of practicing the requirements of active learning by Islamic education teachers studying at King Khalid University. (28) teachers from the eighth level in the Faculties of Education and Sharia participated in this study. The study used the descriptive approach and developed a study tool, which is a note card consisting of (25) statements that measure the practices of Islamic education teachers for the requirements of active learning. After analyzing the data, the results showed that the level of practicing the requirements of active learning by Islamic education teachers was average. The findings showed statistically significant differences between the mean scores of Islamic education teachers' practice of active learning styles due to the variable of the educational stage in favor of the primary stage. In light of the results of the research, it is recommended to conduct training courses for Islamic education teachers on active learning before and during service. The study recommended introducing Islamic education teachers working in the field to active learning strategies in teaching, and its importance, by providing educational documentaries and publications. There is a need to include methods of applying active learning strategies in Islamic education teachers' guidebooks.
\end{abstract}

Keywords Practicing Active Learning, Islamic Education, Teachers, Active Learning

\section{Introduction}

The Islamic education curricula in Saudi Arabia have witnessed a remarkable development in the last few years and a huge jump to pace with the challenges of the times, internal and global changes, and to meet the objectives of education. The Sharia sciences curriculum document in public education states, "The goal of education is to understand Islam in a correct and integrated manner, to instill and spread the Islamic faith, to provide students with Islamic values, teachings, and ideals. It also aims to help students acquire various skills, to develop constructive behavioral trends, to develop society economically, socially and culturally, and to prepare the individual to be a useful member in Building his community" [1].

The development of Islamic education curricula included the four curriculum components: objectives, content, methods, and evaluation. The teacher's book was also designed to guide teachers in following modern teaching strategies such as direct education strategies that include the methodology, dialogue and discussion in some of its applications, and cooperative education and role-learning. It also includes exploration-based teaching strategies that consist of inductive methods and brainstorming, and methods based on constructivist theory such as conceptual maps, problem-solving, the learning cycle, and active learning strategies [2]. Therefore, the traditional model of the class is no longer acceptable to educators in light of these developments. Modern 
education focuses on the active participation of the learner in order to learn, practice, investigate, conclude and solve problems that in turn broaden their scientific perceptions, enhance their ways of thinking and encourage them to act in a logical and social manner [3].

This requires good planning to facilitate the access of knowledge to learners through modern teaching strategies such as active learning to achieve educational goals because a successful teacher is always keen to develop his skills when using them [4].

\subsection{Active Learning}

Relying on the traditional method of teaching and dealing with learners as passive recipients of knowledge is outdated. Therefore, it is necessary to search for other methods that increase the learners' activity and effectiveness, improve their learning, and facilitating their participation, communication and sharing with classmates. The outputs of educational philosophies and models have resulted in a strong impetus towards the interest in active learning, especially after traditional teaching methods have proven ineffective in reaching an active and positive learner who is able to assume responsibility and is prepared for cooperation, dialogue and partnership with other teachers.

The concept of active learning revolves around the learners' participation in the educational process to improve their achievement and to develop their skills and thinking. Active learning refers to the learners' involvement beyond watching, listening and writing what the teacher says, but rather carrying out tasks such as exploring and processing the application of information [1].

Reference [5] defined active learning as a method of learning and teaching at the same time, where learners participate in activities, exercises and projects very effectively through a rich and varied learning environment, with a teacher encouraging them to take responsibility for teaching themselves on their own under his close supervision and pushing them to achieve their goals.

On the other hand [6] defined active learning as the way in which the students learn in a way that allows active participation in the activities that take place in the educational situation. Participation takes students beyond the usual role they play in taking notes, but in taking the initiative in various activities with classmates during interaction with the educational process. The teacher here lectures to a lesser extent and directs students to discover educational materials that lead to greater understanding.

Active learning has its roots in the philosophy of Socrates who said, "I cannot teach anyone anything. I can only make them think." It also appeared in the ideas of Pestalozzi, who envisioned the school as a home institution in which the activities of learners are limited to engaging them in learning through sensory experiences and participation in activities. John Dewey, who along with others advocated for active learning, has been promoting using active learning by teachers in the classroom for more than 50 years [7]. Active learning depends on learners being the focus of the educational process, as they are the ones who choose the activity according to their interests, trends and needs. The basic principles of active learning are consistent with the outcomes of constructive learning theory. Building knowledge is the cornerstone of active learning, as well as interaction and participation in the educational process, which is a continuous process and does not end in time or place. This philosophy includes providing quick feedback in order to guide learners' performance and the necessity to provide participatory tasks as the main processes for these strategies [3]. Among the active learning, strategies are storytelling, role-playing, discussion, brainstorming, think-pair-share, reciprocal teaching, collaborative learning, numbered heads, and question and answer.

\section{Objectives and importance of active learning}

Active learning seeks to achieve a set of goals, including, encouraging learners to acquire many different thinking skills, such as critical, contemplative, creative and inferential thinking, and working on a variety of educational activities that meet the needs and interests of learners in order to achieve the desired goals. It also aims at increasing the self-confidence of the learners in teaching them important knowledge and increasing their motivation towards learning. Using active learning also helps in carrying out work and activities that help students to perform the process of supervision and management of classroom activities [4]. Active learning also increases the creative work of the learners and makes the teaching-learning process more accurate and joyful while increasing the learners' ability to mastery. Moreover, changing the cognitive understanding of the learner positively affects cognitive development [8] and encourages learners to have real learning and life experiences [1].

Active learning is extremely important to learners as it helps them remember (70-90\%) of what they learned even after two weeks. Such results appear with students who participate in group discussions, presentations, and simulations. However, learners who participate in passive activities such as lectures and observation only retain (10-30\%) [9]. Active learning also makes learners more likely to find meaningful solutions to the presented problems and their interpretation, which helps them to learn self-learning strategies by observing the work of others. Using this strategy allows learners to receive feedback and immediate nourishment more frequently. Learners also become more likely to access their prior knowledge, which is the key to learning [1].

Active learning has several characteristics. It puts the learner at the center of the educational process. Learners should plan, prepare and handle learning on their own, participate in learning, organize and control their learning 
[10]. In addition, the activities focus on specific problems, and what is required is to urge the learners to solve them. The teacher is the guide, facilitator, and provider of all methods and techniques in order to provide learners with knowledge. Active learning encourages the principle of effective and enforceable competition and takes into account the feedback derived from educational experiences. Thus, the learner acquires a high level of self-regulation and self-reliance.

\subsection{The Problem of the Study}

Islamic education subject is very important in the life of learners. As a result of the development of Islamic education curricula in Saudi Arabia over the past years according to the principles and foundations of active learning, and efforts made in this regard to keep pace with this development, educators became keen to prepare teachers to follow this development through training and workshops.

Teachers of Islamic education in general education have received qualifications and training to teach in ways and methods that are more modern and effective than the usual methods, including active learning. Reliance on the regular methods is no longer acceptable at present in light of the comprehensive development of Islamic education curricula. There are many theories and methodologies through which the educational process can be viewed, including active learning strategies.

Active learning affected education and presented itself as a very important teaching strategy in different stages of education and various school subjects. It also became evident in organizing the curriculum in line with active learning principles and standards that revolve around how the learner thinks. How does he develop his knowledge? How to improve his achievement? Moreover, how does he apply his knowledge in different situations?

The effectiveness of active learning often depends on teachers and the way they understand their role in the classroom. The main role of teachers begins with designing the classroom environment to include active learning. They should educate the learners about the objectives of teaching, the applied methods, and the expected learning outcomes. They should also present content in an interesting way that is compatible with their needs and improve their understanding so that they can achieve the educational goals (Peko, 2014). Therefore, in response to these developments in terms of curriculum development and teacher preparation in the faculty of Education, this study aimed at identifying the level of practicing the requirements of active learning by Islamic education teachers in teaching.

\subsection{Questions of the Study}

The current study sought to answer these questions:

1. What are the requirements for active learning that should be practiced by Islamic education teachers?
2. What is the level of practicing the requirements of active learning by Islamic education teachers?

3. Are there any statistically significant differences between the levels of practicing the requirements of active learning by Islamic education teachers due to the variable of the educational stage?

\subsection{Objectives of the Study}

This study aims to achieve the following objectives:

Identifying the requirements for practicing active learning by Islamic education teachers.

Identifying the level of practicing active learning by Islamic education teachers.

Finding the existence of significant differences between the levels of practicing the requirements of active learning by Islamic education teachers due to the variable of the educational stage.

\subsection{Significance of the Study}

This study is consistent with the trends and directions of renewal and development in the Islamic education curricula in Saudi Arabia and its reflection on the components of the educational process. The results of this study could benefit decision-makers in education and could be used to reveal the deficiencies in the practice of active learning strategies by Islamic education teachers. The study also urges teachers to join training courses and workshops on teaching Islamic education courses according to active learning strategies.

\subsection{Limitations of the Study}

This study was limited to teachers of Islamic education the eighth level in the Faculties of Education and Sharia who teach Islamic education courses in public education schools in Abha during the 2019/2020 academic year.

\subsection{Definition of terms}

Practicing the requirements of active learning by Islamic education teachers: It is the degree that Islamic education teachers have in employing active learning in their teaching through a set of activities and procedures that teachers use in teaching. In this study, practicing these requirements was measured according to observing teachers 'performance in applying the study tool.

Active learning: reference [11] defines it as activities learners perform in the classroom while learning a specific course. These activities are not limited to listening or simple note-taking. In this study, it is measured by the degree of teachers' practice of active learning as indicated in their answers to the items of the study tool.

\subsection{Previous Studies}

Researchers have been interested in active learning and its strategies in their studies in all different sciences, 
including Islamic education. Reference [12] identified the effect of active learning on academic achievement in the Prophetic Biography subject among students of the Faculties of Education in Baghdad. The sample of the study consisted of (51) students. The researcher used the experimental method by adjusting some variables. The results of the study demonstrated that the experimental group that studied the biography of the Prophet through active learning had a better performance than the control group that studied using the traditional method.

Reference [13] investigated the effectiveness of active learning strategies on the development of self-efficacy and academic achievement. The study was applied to (59) male and female students. The researchers developed a self-efficacy scale and an achievement test in the educational counseling subject. Findings showed the presence of differences between the scores of students in the two groups in self-efficacy and academic achievement. Students who received active learning performed better.

On the other hand, [14] explored sing the peer education strategy for developing active learning skills among sixth-grade students in the Arabic language in Jordan. The study was applied to (61) students, and the researchers prepared an open-end test as a study tool that takes into account developing active learning skills. The findings showed the improvement of the students in the experimental group after receiving instructions using this strategy.

Reference [8] identified the effect of teaching Arabic using active learning strategies on developing creative thinking among sixth-grade students. The researcher used the quasi-experimental approach and applied the developed tool on a sample of $t(50)$ students. The results showed the group that studied using active learning strategies scored better in the post-application of the post-thinking test and its three skills.

Reference [15] investigated the degree to which mathematics teachers use active learning strategies and the obstacles to their use. The researcher used the descriptive survey method and was applied on (87) female teachers. The results showed that the degree of using active learning strategies by math teachers was high. The results also showed that the variables of academic qualification and level of experience did not affect the differences between teachers 'answers about the degree of using active learning.

While [16] investigated the obstacles against using active learning strategies by Arabic language teachers at the basic stage. The study used the descriptive and analytical method and was applied to (450) male and female teachers and (24) supervisors. The results concluded that the most obstacles facing Arabic language teachers are those related to the educational environment from the teachers' perspectives. Other obstacles facing Arabic language teachers from the perspectives of supervisors included the effective use of active learning strategies.
Reference [17] reviewed the relationship between practices in Islamic education and active learning activities. Active learning proved to be effective. However, students who prefer active learning compared to other students still had concerns about using such a method. The study suggested different ways for Islamic education teachers in the secondary stage to practice active learning. The study found that there are five different appropriate methods applied in Islamic schools.

Reference [3] identified the effectiveness of teaching using active learning in providing second-grade students with national and life knowledge. The sample included (82) male and female students, on whom the national and life knowledge test was applied. The results showed that the mean scores of the students who conducted the test were higher after receiving instructions using active learning.

On the other hand, [18] explored using active learning strategies in teaching jurisprudence among general section students. The study described how to plan, implement and evaluate active learning strategies in teaching jurisprudence among students of Aliyah Nahdlatual School in Java, Indonesia. The researcher used a qualitative approach to obtain data. The results concluded that teachers should be more selective when preparing learning plans, in addition to using lecture, question and answer, discussion methods, increasing teachers' ability to apply techniques and making students more active.

Reference [19] explored the level of practicing active learning strategies during field training according to female graduate students from the Faculty of Education at the University of Hail. The study aimed at identifying the degree of familiarity with the principles and theoretical foundations of these strategies and the obstacles to their use during the field-training period. The descriptive and analytical method was used, and (53) students answered the questionnaire developed for this study. The results showed that the domain of familiarity with the theoretical foundations of education strategies as a whole received a high degree. The results showed an absence of differences based on the variable of age and the accumulative average.

Reference [20] conducted a study aimed at measuring the impact of using an active learning-based training program in the development of teachers' skills in Sharia science and their attitudes towards it in Saudi Arabia. The researchers used both descriptive and experimental approaches. The two study tools were the observation card and the scale of the trend towards the material, which was distributed to (34) teachers. The results showed differences in teachers' skills and attitudes after answering the observation card for teaching skills.

While [21] identified the effectiveness of active learning strategies on developing inferential thinking skills among fourth-grade middle school students in Islamic education and their attitudes towards it. 59 students received two tests, the first is a test for inferential thinking skills, and the second is a measure of the attitudes towards the material. 
The results showed higher mean scores in the development of inferential thinking skills of students who received the training. The attitudes of students towards Islamic education were also positive.

Finally, [22] discussed using active learning strategies in teaching jurisprudence in the Islamic Boarding School. The researchers used the qualitative method to collect data. Data collection procedures were also implemented through various books, articles, theses and scientific research that discussed the topic of jurisprudence in this school. The results showed that the active learning method could be used in teaching jurisprudence. The students were also enthusiastic, engaged and interested in the study of jurisprudence using active learning strategy.

It is noted from previous studies that there is a positive and noticeable effect of active learning strategies in teaching and various disciplines such as mathematics, Islamic education, Arabic language, computer and national education. Active learning seems to have a positive impact on the development of various thinking skills such as critical thinking, creative thinking, inferential thinking and the development of attitudes towards the material, as well as the development of teamwork and active participation by students.

\section{Methodology}

\subsection{Sampling}

The study population consisted of all teachers of Islamic education-the eighth level of the Faculties of Education and Sharia-who teach Islamic education courses for the 2019-2020 academic year. The study sample consisted of (28) students-teachers teaching Islamic education courses in the schools of Abha for the 2019-2020 academic year, distributed according to Table 1.

Table 1. Distribution of the sample of the study according to the independent variables

\begin{tabular}{ccc}
\hline Variable & Level & No. \\
\hline Educational stage & Elementary & 14 \\
& Middle school & 14 \\
Total & 28 & \\
\hline
\end{tabular}

\subsection{The Instrument of the Study}

The study instrument was prepared after reviewing the educational literature and previous studies related to the topic and the active learning assessment card as developed in the sixth edition of the school leadership indicators 2018/2019. The study instrument consisted of a notecard that measures the level of practicing the requirements of active learning by Islamic education teachers. The instruments consisted of the first form of (31) paragraphs according to the five-point Likert scale. After it was presented to the judges, the paragraphs of the instrument became (25) paragraphs. The five-point Likert scale was adopted as a measurement in the notecard. Each paragraph in the notecard represented five alternatives, which were very high, high, medium, low, and very low. These alternatives were given the following grades: (5 - 4 - 3 - 2 1 ), respectively. Table (2) shows degrees of the values and degree of practice for the requirements of active learning.

Table 2. Degrees of weighted value and the level of practicing the requirements of active learning by Islamic education teachers according to Likert's five-point scale

\begin{tabular}{ccc}
\hline Category & Value of category & Level of practice \\
\hline 1 & $1.8-0$ & Very low \\
2 & $2.60-1.81$ & Low \\
3 & $3.40-2.61$ & Medium \\
4 & $4.20-3.41$ & High \\
5 & $5-4.21$ & Very high \\
\hline
\end{tabular}

\subsubsection{Validity}

The validity of the notecard was verified through the following two methods:

External validity: To ensure the validity of the notecard and its suitability, it was presented to a group of judges specialized in curricula and teaching methods at the Faculty of Education at King Khalid University in Abha. The judges indicated that some amendments needed to be made to the method of drafting the paragraphs by deleting and adding. After making the required amendments, the judges indicated the validity of the instrument for application to the study sample, where the paragraphs that obtained an agreement percentage exceeding $90 \%$ were approved.

Internal validity: After obtaining the external validity, the researcher applied the tool to an exploratory sample other than the study sample, which consisted of (3) teachers. Pearson's' correlation coefficient was measured for each item of the tool and the total score. The value of the Pearson correlation coefficient between all paragraphs and the total score of the card was (0.835) positive, which is statistically significant at the level of significance (0.01) and indicates the consistency of the paragraphs of the card.

\subsubsection{Reliability}

The reliability of the instrument was verified using stability across individuals. The researcher used another observer equivalent to him in terms of academic degree and years of academic experience, by applying the observation card to a pilot sample of (3) teacher. To determine the coefficient of reliability, the Cooper equation was used, which states as follows:

Stability Coefficient $=$ the number of times of agreement between the first and second observer x 100\%/The number of times of agreement + the number of times of disagreement

The value of the stability coefficient was $(86,908)$, which is an appropriate stability value and suitable for this study. 


\subsection{Variables of the Study}

The independent variables of the study were the educational stages, elementary and middle school. The dependent variable was responding to the paragraphs of the notecard.

\subsection{Data Analysis}

After unpacking the responses of the study sample individuals into the Statistical Package for Social Sciences (SPSS) program, the following statistical treatments were used:

Frequencies, mean scores, percentages, and standard deviations.

Mann-Whitney test of two independent variables.

The criterion that was relied upon in correcting the notecard for positive items is very high (5 degrees), high (4 degrees), medium (3 degrees), low (two degrees), very low (one degree), and for negative items is very high (1), high (2 marks), medium (3 marks), low (4 marks), very low (5 marks).

\subsection{Procedures}

The study was carried out according to the following procedures:

1. Review the literature and previous studies related to active learning.
2. Preparing a list of the active learning requirements that should be used by Islamic education teachers.

3. Presenting the list to a group of specialized judges to provide their opinions and make amendments accordingly.

4. Selecting the study sample purposefully, who were the students supervised by the researcher in the field.

5. Determining the time of application of the study, which was the academic year 2019/2020.

6. Applying the instrument to the pilot sample, which is outside the study sample, to ensure the validity of internal consistency and reliability.

7. Applying the study instrument to the study sample, collecting data and unloading it through statistical packages (SPSS), to reach the results of the study, then discussing them and coming up with appropriate recommendations.

\section{Results and Discussion}

First: The first question, which states "What are the requirements for active learning that should be practiced by Islamic education teachers?"

To answer this question, the researcher consulted the previous literature related to the topic, and then prepared a list of active learning requirements that should be used by Islamic education teachers, which resulted in (25) paragraphs as in Table 3.

Table 3. The list of the active learning requirements that should be used by Islamic education teachers

\begin{tabular}{|c|c|c|c|}
\hline NO. & Paragraph & NO. & Paragraph \\
\hline 1 & Using the learning resources available in the school & 14 & $\begin{array}{l}\text { Focusing on communicating, interacting and sharing with } \\
\text { each other to clarify issues }\end{array}$ \\
\hline 2 & Discussing with the learners how to reach the goals & 15 & $\begin{array}{l}\text { Analyzing the assessment results of learners to provide } \\
\text { feedback, improve and design teaching methods to meet } \\
\text { their needs }\end{array}$ \\
\hline 3 & $\begin{array}{l}\text { Assigning learners to use previous variables and } \\
\text { knowledge to serve the goals. }\end{array}$ & 16 & $\begin{array}{c}\text { Activating active learning strategies that develop dialogue } \\
\text { and social skills }\end{array}$ \\
\hline 4 & $\begin{array}{c}\text { Encouraging learners to initiate themselves by distributing } \\
\text { roles and identifying methods for achieving them }\end{array}$ & 17 & $\begin{array}{l}\text { Linking educational content with students' realities and } \\
\text { their world } \\
\end{array}$ \\
\hline 5 & $\begin{array}{l}\text { Presenting problems and activities that make learners } \\
\text { think. }\end{array}$ & 18 & $\begin{array}{l}\text { Providing an attractive learning environment that increases } \\
\text { learning motivation }\end{array}$ \\
\hline 6 & Learners apply acquired experiences in new life situations & 19 & Finding a balance between individual and group activities \\
\hline 7 & $\begin{array}{l}\text { Investing learners' technology and knowledge resources in } \\
\text { solving problems and activities with the support of the } \\
\text { teacher. }\end{array}$ & 20 & $\begin{array}{l}\text { Providing the opportunity for learners to talk about their } \\
\text { ideas and formulations in their own ways and respecting } \\
\text { the point of view of others. }\end{array}$ \\
\hline 8 & $\begin{array}{l}\text { Learners understand their role in the lesson in achieving } \\
\text { the lesson objectives }\end{array}$ & 21 & Urging students to search for information \\
\hline 9 & $\begin{array}{l}\text { The teacher encourages students to ask thought-provoking } \\
\text { questions to their peers }\end{array}$ & 22 & Participation of learners in setting goals \\
\hline 10 & Urging learners to evaluate their learning & 23 & $\begin{array}{l}\text { Increasing self-confidence of learners by assigning them } \\
\text { some activities }\end{array}$ \\
\hline 11 & Diversification of appropriate activities for learners. & 24 & Increasing learners' motivation to learn. \\
\hline 12 & $\begin{array}{c}\text { Participation of all learners according to a clear classroom } \\
\text { system in multiple ways. } \\
\end{array}$ & 25 & $\begin{array}{c}\text { Diversification of appropriate educational activities for } \\
\text { learners. }\end{array}$ \\
\hline 13 & $\begin{array}{c}\text { The use of active learning strategies emanating from } \\
\text { constructivism theory. }\end{array}$ & & \\
\hline
\end{tabular}


Second: The second question, which states, "What is the level of practicing the requirements of active learning by Islamic education teachers?"
To answer this question, the mean and standard deviations of the study sample on the notecard were extracted as shown in Table 4.

Table 4. Frequencies mean scores and standard deviations of the instrument's paragraphs about the level of practicing the requirements of active learning by Islamic education teachers. $\mathrm{N}=28$

\begin{tabular}{|c|c|c|c|c|c|c|c|c|c|c|}
\hline \multirow[b]{2}{*}{$\mathbf{N}$} & \multirow[b]{2}{*}{ Paragraph } & \multicolumn{5}{|c|}{ Frequencies } & \multirow{2}{*}{$\begin{array}{l}\text { Mean } \\
\text { score }\end{array}$} & \multirow[b]{2}{*}{ St. dev } & \multirow{2}{*}{$\begin{array}{l}\text { Level of } \\
\text { practice }\end{array}$} & \multirow{2}{*}{$\begin{array}{c}\text { Ran } \\
\mathbf{k}\end{array}$} \\
\hline & & $\begin{array}{l}\text { Very } \\
\text { high }\end{array}$ & High & Medium & Low & $\begin{array}{l}\text { Very } \\
\text { low }\end{array}$ & & & & \\
\hline 1 & $\begin{array}{l}\text { Using the learning resources } \\
\text { available in the school }\end{array}$ & 9 & 8 & 11 & 0 & 0 & 3.929 & 0.814 & High & 2 \\
\hline 2 & $\begin{array}{l}\text { Discussing with the learners } \\
\text { how to reach the goals }\end{array}$ & 0 & 5 & 10 & 8 & 5 & 2.536 & 0.948 & Low & 17 \\
\hline 3 & $\begin{array}{l}\text { Assigning learners to use } \\
\text { previous variables and } \\
\text { knowledge to serve the goals. }\end{array}$ & 0 & 0 & 28 & 0 & 0 & 3.000 & 0.000 & Medium & 10 \\
\hline 4 & $\begin{array}{lr}\text { Encouraging learners } & \text { to } \\
\text { initiate themselves } & \text { by } \\
\text { distributing roles and } \\
\text { identifying methods for } \\
\text { achieving them }\end{array}$ & 9 & 6 & 13 & 0 & 0 & 3.857 & 0.845 & High & 3 \\
\hline 5 & $\begin{array}{l}\text { Presenting problems and } \\
\text { activities that make learners } \\
\text { think. }\end{array}$ & 0 & 0 & 0 & 14 & 14 & 1.500 & 0.483 & Very low & 18 \\
\hline 6 & $\begin{array}{l}\text { Learners apply } \\
\begin{array}{l}\text { acquired } \\
\text { experiences in new life } \\
\text { situations }\end{array}\end{array}$ & 0 & 17 & 11 & 0 & 0 & 3.607 & 0.472 & Medium & 6 \\
\hline 7 & $\begin{array}{l}\text { Investing learners' technology } \\
\text { and knowledge resources in } \\
\text { solving problems and } \\
\text { activities with the support of } \\
\text { the teacher. }\end{array}$ & 0 & 9 & 9 & 0 & 8 & 2.536 & 1.156 & High & 17 \\
\hline 8 & $\begin{array}{l}\text { Learners understand their role } \\
\text { in the lesson in achieving the } \\
\text { lesson objectives }\end{array}$ & 1 & 10 & 15 & 2 & 0 & 3.357 & 0.644 & Medium & 7 \\
\hline 9 & $\begin{array}{l}\text { The teacher encourages } \\
\text { students to ask } \\
\text { thought-provoking questions } \\
\text { to their peers }\end{array}$ & 0 & 6 & 12 & 5 & 5 & 2.679 & 0.968 & High & 14 \\
\hline 10 & $\begin{array}{l}\text { Urging learners to evaluate } \\
\text { their learning }\end{array}$ & 0 & 7 & 8 & 8 & 5 & 2.607 & 1.011 & Medium & 15 \\
\hline 11 & $\begin{array}{l}\text { Diversification of appropriate } \\
\text { activities for learners. }\end{array}$ & 21 & 0 & 7 & 0 & 0 & 4.500 & 0.837 & Very low & 1 \\
\hline 12 & $\begin{array}{l}\text { Participation of all learners } \\
\text { according to a clear classroom } \\
\text { system in multiple ways. }\end{array}$ & 7 & 8 & 13 & 0 & 0 & 3.786 & 0.790 & High & 4 \\
\hline 13 & $\begin{array}{l}\text { The use of active learning } \\
\text { strategies emanating from } \\
\text { constructivism theory. }\end{array}$ & 0 & 0 & 0 & 14 & 14 & 1.500 & 0.483 & Very low & 18 \\
\hline 14 & $\begin{array}{l}\text { Focusing on communicating, } \\
\text { interacting and sharing with } \\
\text { each other to clarify issues }\end{array}$ & 0 & 17 & 11 & 0 & 0 & 3.607 & 0.472 & Medium & 6 \\
\hline 15 & $\begin{array}{l}\text { Analyzing the assessment } \\
\text { results of learners to provide } \\
\text { feedback, improve and design } \\
\text { teaching methods to meet } \\
\text { their needs }\end{array}$ & 0 & 8 & 10 & 0 & 10 & 2.571 & 1.195 & Low & 16 \\
\hline 16 & $\begin{array}{lcc}\text { Activating active learning } \\
\text { strategies that develop } \\
\text { dialogue and social skills } \\
\end{array}$ & 0 & 0 & 0 & 14 & 14 & 1.500 & 0.483 & Very low & 18 \\
\hline 17 & $\begin{array}{l}\text { Linking educational content } \\
\text { with students' realities and } \\
\text { their world }\end{array}$ & 0 & 19 & 9 & 0 & 0 & 3.679 & 0.451 & High & 5 \\
\hline 18 & $\begin{array}{l}\text { Providing an attractive } \\
\text { learning environment that } \\
\text { increases learning motivation }\end{array}$ & 0 & 12 & 12 & 0 & 4 & 3.143 & 0.956 & Medium & 9 \\
\hline
\end{tabular}


Table 4 Continued

\begin{tabular}{|l|l|c|c|c|c|c|c|c|c|c|}
\hline $\mathbf{1 9}$ & $\begin{array}{l}\text { Finding a balance between } \\
\text { individual and group } \\
\text { activities }\end{array}$ & 1 & 12 & 11 & 4 & 0 & 3.357 & 0.740 & Medium & $\mathbf{7}$ \\
\hline $\mathbf{2 0}$ & $\begin{array}{l}\text { Providing the opportunity for } \\
\text { learners to talk about their } \\
\text { ideas and formulations in their } \\
\text { own ways and respecting the } \\
\text { point of view of others. }\end{array}$ & 0 & 11 & 7 & 5 & 5 & 2.857 & 1.087 & Medium & $\mathbf{1 2}$ \\
\hline $\mathbf{2 1}$ & $\begin{array}{l}\text { Urging students to search for } \\
\text { information }\end{array}$ & 0 & 11 & 8 & 4 & 5 & 2.893 & 1.075 & Medium & $\mathbf{1 1}$ \\
\hline $\mathbf{2 2}$ & $\begin{array}{l}\text { Participation of learners in } \\
\text { setting goals }\end{array}$ & 0 & 0 & 28 & 0 & 0 & 3.000 & 0.000 & Medium & $\mathbf{1 0}$ \\
\hline $\mathbf{2 3}$ & $\begin{array}{l}\text { Increasing self-confidence of } \\
\text { learners by assigning them } \\
\text { some activities }\end{array}$ & 7 & 7 & 5 & 5 & 4 & 3.286 & 1.338 & Medium & $\mathbf{8}$ \\
\hline $\mathbf{2 4}$ & $\begin{array}{l}\text { Increasing } \\
\text { motivation to learn. }\end{array}$ & 7 & 4 & 1 & 7 & 9 & 2.750 & 1.563 & Medium & $\mathbf{1 3}$ \\
\hline $\mathbf{2 5}$ & $\begin{array}{l}\text { Diversification of appropriate } \\
\text { educational activities for } \\
\text { learners. }\end{array}$ & 4 & 15 & 8 & 1 & 0 & 3.786 & 0.700 & High & $\mathbf{4}$ \\
\hline
\end{tabular}

Table 4 revealed that the total mean score of practicing the requirements of active learning by Islamic education teachers was (3.032) and with a standard deviation of (0.78044). This indicates that Islamic education teachers practice active learning with a medium degree. This may be due to the recent development of Islamic education curricula based on active learning and the lack of experience of many teachers and their weak knowledge of the requirements of active learning. In addition, many teachers have not attended training courses on teaching the new curricula according to active learning and some teachers still use traditional methods of teaching.

It is noted from Table 4 that the most frequently applied requirements for active learning during teaching by teachers are "diversification of activities suitable for learners", as the mean score was (4.50) and the standard deviation was (0.837). This may be due to the importance of activities in the educational process as a whole, and this is what modern curricula require, which makes it imperative for the teacher to provide learners with appropriate activities. Another requirement used frequently was "using the learning resources available in the school," as the mean score was $(3,929)$ and the standard deviation was (0.814). The reason for this may be attributed to the requirements of the modern educational process for the use of learning resources, the availability of these resources in all schools and the ease of obtaining them without burdens.

It is also noticed from Table 4 that the least requirements for active learning applied during teaching by teachers are "using active learning strategies emanating from the constructivist theory" where the mean score was (1.50) and a standard deviation of (0.484). This may be attributed to the fact that these strategies are modern and require intensive training courses. Another requirement that got less practice is "presenting problems and activities that motivate learners to think", where the mean score was (1.50) and a standard deviation of (0.483). This may be attributed to the teacher's commitment to the content of the presented curriculum, as well as to the lack of time that prevents him from presenting many problems to learners. These results agree with previous studies conducted in this field $[12,14,8,3]$. These studies showed the positive impact of using active learning in the classrooms.

Third: The third question, which states, "Are there any statistically significant differences between the levels of practicing the requirements of active learning by Islamic education teachers due to the variable of the educational stage?”

To answer this question, the total and mean ranks were extracted through the Mann-Whitney test for two independent variables as shown in Table 5.

Table 5. Mann-Whitney test for the significance of the differences between the researcher's estimates of the level of practicing the requirements of active learning by Islamic education teachers attributable to the educational stage

\begin{tabular}{cccccc}
\hline Stage & No. & $\begin{array}{c}\text { Sum of } \\
\text { ranks }\end{array}$ & U value & $\begin{array}{c}\mathbf{Z} \\
\text { value }\end{array}$ & Sig. \\
\hline $\begin{array}{c}\text { Elementary } \\
\text { stage }\end{array}$ & 14 & 258.50 & & & \\
$\begin{array}{c}\text { Middle } \\
\text { school }\end{array}$ & 14 & 147.50 & & & \\
\hline
\end{tabular}

Table 5 indicates that there are statistically significant differences between the mean scores of the researcher's estimates of the level of practicing active learning strategies by Islamic education students in Sharia and elementary education at King Khalid University due to the educational stage. The value of Mann Whitney $\mathrm{Z}$ was (2.556) and it is statistically significant at (.011) and in favor of the elementary stage. This result may be attributed to the ease of courses in the elementary stage, and the presence of equipment, material capabilities, learning 
resources and educational aids in elementary schools, which could be better than in middle schools. The interest of parents in their children in the elementary stage more than the intermediate stage could be also a contributing factor. In addition, primary school students follow the teacher's instructions and directions and have better adherence than middle school students who go through adolescence phases and the physiological changes related to it. This gives the teacher more space to raise his level and apply the requirements of active learning.

\section{Recommendations}

The study recommends holding training courses for Islamic education teachers both before and during service. The study also recommends introducing teachers working in the field to active learning strategies in teaching by providing educational films and publications related to this. There is a need to include techniques of using active learning strategies in teachers' books to enable teachers to use them in the classrooms.

\section{Acknowledgments}

The author would like to express their gratitude to Kink Khalid University, Saudi Arabia for providing administrative and technical support.

\section{REFERENCES}

[1] Ministry of Education. "Active learning, prepared by the General Administration of Training and Scholarships," Riyadh. 2015. https://edu.moe.gov.sa/Kharj/Departments/G irlsEducational/EducationalsupervisionGirls/Pages/ActiveL earning.aspx?AspxAutoDetectCookieSupport $=1$ accessed on 15 July 2020.

[2] Al-Khalif H, Hashem K A. "Chapters in teaching Islamic education.” 7th ed, Riyadh, Al-Rashed Library. 2015

[3] Al-Asi W A. "The Effectiveness of Teaching Using Active Learning in Providing Students of the Second Grade Basic National and Life Knowledge.” Journal of the Islamic University for Educational and Psychological Studies, 22 (1), 135-151. 2019.

[4] AbdulKarim A M, Qutub I. M. "The Effectiveness of Active Learning Strategies for Teaching Islamic Education in Achievement and Self-Confidence among Intermediate School Students in the Kingdom of Saudi Arabia." Al-Madinah International University Journal, 31, 352-403. 2020.

[5] Saadeh J, Ishtaieh J, Zamil M, Abu Arqoub H, Akl F. "Active learning between theory and practice." Dar $\mathrm{Al}$ Shorouk for publishing and distribution. 2011.
[6] Hijazy J H, Al-Mahdi H Y. “The effectiveness a strategy in active, participatory learning based on the web on improving the social competence and learning motivation of students of the Faculty of Education at Al-Aqsa University.” Al-Aqsa Magazine, Human Sciences Series, 1, 31-66. 2016.

[7] Demirci, C. "The Effect of Active Learning Approach on Attitudes of 7th Grade Students.” International Journal of Instruction, 10(4), 129-144. 2017.

[8] Twaij S S. "The effect of teaching Arabic using active learning strategies on developing creative thinking among sixth grade students.” Arab Journal of Science and Research Publishing - Journal of Educational and Psychological Sciences, 1 (1), 38-51. 2017.

[9] Shaaruddin J, Mohamad M,. "Identifying the Effectiveness of Active Learning Strategies and Benefits in Curriculum and Pedagogy Course for Undergraduate TESL Students.” Creative Education, 8, 2312-2324. 2017.

[10] Peko A, Varga R. “Active Learning in Classrooms.” Život i škola, 31 (60), str. 59. - 75. 2014.

[11] Felder R M, Brent R. “Active Learning: An Introduction,” ASQ Higher Education Brief, 2(4), 1-5. 2009.

[12] Hussain N A. "The Effect of Active Learning in the Achievement of the Prophetic Biography Subject for Students of the Faculties of Education in Baghdad.” Iraqi Society for Educational and Psychological Sciences, Journal of Educational and Psychological Sciences 82, 507-586. 2011.

[13] Asha E K, Shalabi I A, Abu Awwad F M, Abd I R. “The effectiveness of active learning strategies on developing self-efficacy and academic achievement among students of the Faculty of Educational Sciences of the UNRWA." Damascus University Journal -28 (1), 519-542. 2012.

[14] Al-Qadi H M, Al-Oun I S, Al-Barri Q N. “The Effect of Using the Strategy of Peer Teaching on Developing the Active Learning Skills of the Basic Sixth Grade Students in Arabic Language in Jordan.” Journal of Education and Practice, 4(19), 19, 2013.

[15] Al-Mohammadi I S. "The Degree of using Active Learning Strategies by Mathematics Teachers.” The International Journal of Education, 2, 55-80. 2018.

[16] Al-Jabari M I. "Barriers to the using active learning strategies by Arabic language teachers in the basic stage." Palestine University Journal for Research and Studies. 7 (4), 279-310. 2018.

[17] Mustaffa A. "Active Learning: Activities and practices in Islamic Subjects." International Journal of Academic Research in Business and Social Sciences, 8(12), 2121-2127. 2018.

[18] Anwar M A. "Management of Active Learning Strategies in Learning Fiqh in General Department Students.” Journal of Islamic Education (AJIE), Volume 3, Issue 2,212-223. 2019.

[19] Ayasrah W M. "The level of practicing active learning strategies during field training from the viewpoint of female graduate students from the Faculty of Education at the University of Hail." Journal of Educational and Psychological Sciences, 3 (27), 70-88. 2019. 
[20] Al-Raddadi F A, Ali A M, Mabruk I M. "The effectiveness of a training program based on active learning in developing the teaching skills of teachers of Sharia science and their attitudes towards it in the Kingdom of Saudi Arabia.” The Arab Journal of Science and Research Publishing - Journal of Educational and Psychological Sciences, 3 (27), 45-69. 2019.

[21] Qasim R F, Abdul-Rahman A S. "Teaching Islamic Education with Active Learning Strategies and its Impact on
Developing Inferential Thinking Skills for Fourth Intermediate Literary Students and Their Attitude Toward University of Mosul.” College of Basic Education Research Journal 3 (15), 303-330. 2019.

[22] Mansir F, Tumin \& Purnomo H. "The Use of Active Learning Methods in Learning Fiqh Subject Islamic Boarding School.” Lentera Pendidikan: Journal Ilmu Tarbiyah dan Keguruan, 23(1), 173-182. 2020. 